\title{
GOVERNANCE AND FINANCIAL DIFFICULTIES OF CONVENTIONAL BANKS
}

\author{
La Ode Sumail \\ Sekolah Tinggi Ilmu Ekonomi Makassar (STIEM Bongaya) Indonesia
}

\begin{abstract}
This study examines the connection between governance, financial performance, and financial difficulties of 27 conventional private banks during the pe3riod of 2015-2018. In order to meet the accuracy of the model in the regression analysis, the Lagrange Multiplier test was previously performed so that the Fixed Effects model was chosen. The relationship of insider ownership with ROA tends to be in the shape of inversed-U and the relationship between institutional ownership and ROA is significantly positive. The relationship between ROA and financial difficulties is significantly negative. Older or established large scale banks tend to have high ROA. This happens because the greater the assets, the healthier the cash flow of the bank, so that the potential for return of asset is quite high and financial difficulties tend to be low or avoidable.
\end{abstract}

Keywords: institutional ownership, insider ownership, governance, financial difficulty

\section{INTRODUCTION}

Banks that tend to experience financial distress are banks that show declining financial conditions such as declining profits, liquidity problems, and increasing bad loans (Farooq, Jibran Qamar, \& Haque, 2018). Profit decreases and bad credit increases tend to disrupt bank cash flow and will encourage financial risks to emerge. As a result, banks will experience liquidity problems.

Financial difficulties can occur when the bank is mismanaged. Therefore, poor corporate governance and lack of quality can result in poor financial performance. In fact, good corporate governance and quality will improve financial performance (Bhagat \& Bolton, 2008) and companies will avoid financial difficulties (Al-Tamimi, 2012). The big question is: is it true that a

\footnotetext{
*Corresponding Author.

e-mail: odesumail@yahoo.co.id
} 
significant decline in profits is caused by fragile governance, thus causing the unhealthiness of financial performance? Governance is crucial in managing operational systems and assets, so much so that financial performance becomes strong and the institution avoids financial difficulties. Therefore, better governance practices will lead to better financial performance, such as increased cash flow, profitability, increase in the company's market as expected by investors, and a reduction in capital costs (Reddy, Locke, \& Scrimgeour, 2010).

Good bank governance is not just a step of compliance, but it establishes strong ties so as to produce a strong commitment to implementing GCG principles such as transparency, accountability, responsibility, independence, fairness, and equality and discipline (Klapper \& Love, 2004; Oba, Ozsoy, \& Atakan, 2010) throughout all levels of management. It is hoped that work culture behavior will grow as reflected by GCG culture so that financial performance will be strong and avoid financial difficulties. The strong behavior of GCG work culture will increase shareholder confidence in the process of governance and protection to investors (Klapper \& Love, 2004; Martynova \& Renneboog, 2008).

To confirm the relationship between insider ownership and inverted U-shaped or non-linear performance as reported (Shin \& Tsung, 2009), this study tries to explore the trend of increasing insider ownership variables with financial performance and to deepen insider ownership in certain conditions with financial performance. Institutional ownership plays an important role in bank governance, namely the role of monitoring to minimize bankruptcy costs, and to signal good performance (Al-najjar, 2010). Therefore, institutional ownership is placed as an explanatory variable on financial performance. Furthermore, this study also puts the firm size, company age, and sales growth as control variables in order to get a full explanation that has not been explained by explanatory variables.

This article is organized as follows: section two presents a review of the literature and previous research. In this section, the research hypothesis is also presented.

\section{LITERATURE REVIEW AND PAST RESEARCHES}

Corporate governance appears as a response to potential conflicts or conflicts of interest between parties with a stake in the company structure. 
Gumanti (2017: 267) mapped the source of the emergence of conflicts of interest. First, different actors have different goals and preferences. Second, the actors do not have perfect information on every action carried out by other actors. For banks that have public status or are public companies, governance is a fundamental aspect in improving financial performance (look eg, Anderson \& Campbell, 2004) so that financial difficulties will be avoidable. The inability to bridge the interests of various parties due to uncertainty and information asymmetries will potentially cause agency problems. As a result, financial performance becomes unacceptable and companies tend to be exposed to financial pressures. Therefore, governance through strengthening insider ownership and the role of institutional ownership can at least reduce agency problems.

Empirical articles such as McConnell, Servaes, \& Lins, (2008) assume that increasing insider ownership can reduce agency problems. The reason behind this assumption is that the greater the portion of insider share ownership, the stronger the manager or insider's drive to act in favor of the owner's interests such as making attractive investments so as to increase the company's profitability or increase the company's market price. Therefore, insider ownership has a strong and significant effect on financial performance. Chen, Hou, \& Lee, (2012) completed an understanding of the relationship of insider managerial ownership to the financial performance of public tourism hotels in Taiwan during the period of 1997-2009, and showed that ROA and Tobin's Q had a strong relationship with hotel financial performance, so much so that the relationship was in the shape of an inversed-U or non-linear. Interestingly, Iqbal \& Santhakumar (2018) conducted a search in India that the average insider trader obtained an asset return (ROA) of 19.28 percent compared to outside investors. That is, insider ownership has a strong relationship with financial performance. Long before, Bhabra (2007) had a special view that when insider ownership of 14 percent had a strong influence on the value of the company and ownership above 40 percent would be inversely proportional to the value of the company.

Hypothesis 1: insider ownership has an inversed U-shaped relation to financial performance. 
Institutional ownership is used as a measure or proxy for corporate governance. This argument is based on empirical facts that institutional owners can influence management performance and activities. Thus, institutional ownership plays an important role in corporate governance such as the role of monitoring to minimize bankruptcy costs, sending information to other shareholders, and signaling good performance (see Al-najjar, 2010). This is because institutional owners have information advantage over other shareholders (Arjoon, Bougheas, \& Milner, 2016) and can invest in companies that perform better (see Demiralp, D’Mello, Schlingemann, \& Subramaniam, 2011).

Empirical evidence that has been presented so far by Abdelsalam, El-Masry, \& Elsegini (2008); Bhattacharya \& Graham (2009); and Elyasiani \& Jia (2010), tend to support the hypothesis that the stronger institutional ownership, the better the financial performance. Ahmad \& Jusoh's article (2014) had investigated 730 public companies in Malaysia using panel data that institutional ownerships have a positive and significant relationship with Tobin's Q and share prices. Therefore, the involvement of institutional investors in monitoring and controlling activities reduces agency conflicts and improves company performance. In fact, institutional investors tend to be more careful about the company's stock return performance (see Belghitar, Clark, \& Kassimatis, 2011). Furthermore, Cornett, Marcus, Saunders, \& Tehranian (2007) have similar views, stating that there is a significant relationship between the return on operating cash flow of the company and the percentage of institutional share ownership and the number of institutional shareholders. However, Shin \& Tsung (2009) found a different view, stating that institutional ownership of government and ownership of statutory bodies have a significant negative correlation with company performance.

Hypothesis 2: Institutional ownership is positively related to financial performance.

Good financial performance is a snapshot of a well-managed company with reduced financial difficulties. Empirical evidence by Mselmi, Lahiani, \& Hamza (2017) reported that low profitability implies low financial performance and thus resulting in financial difficulties. This is suspected because governance is fragile 
or weak. Shahwan (2015) had a similar view, stating that poor quality corporate governance practices will have an impact on poor financial performance and the company will potentially experience financial difficulties. Much earlier, Lee \& Yeh (2004) stated that weak corporate governance is caused by several types of ownership structures and the composition of the board tends to result in a takeover of minority interests, which in turn reduces the value of the company and thus increases the potential to experience financial difficulties. Hence, governance must be strong like internal and external control mechanisms. Simpson \& Gleason (1999) have investigated the relationship between the ownership structure of the board of directors and the internal control mechanism related to the survival of banking companies. Empirical results indicate that the possibility of financial difficulties will be lower when the company only has one CEO and a board of directors In addition, the role of institutional ownership is to control financial performance and overcome financial difficulties. Articles such as by Li, Wang, \& Deng (2008); and Manzaneque, Priego, \& Merino (2016) reported that institutional ownership negatively influences financial difficulties. That is, if there is good governance, then financial performance is also good and financial difficulties will decline.

Hypothesis 3: Financial performance is negatively related to financial difficulties.

\section{METHODOLOGY AND ANALYTICAL PROCEDURES}

The research sample is a private conventional bank on the Indonesia Stock Exchange that has sufficient information, which is as much as 27 during 20152018, 109 number of observations. To achieve the objectives of this study, the analysis went through two stages. First, to put the financial performance variable (FP) influenced by insider ownership (ISD) and institutional ownership (IST) by including control variables, namely company size (SIZE), company age (AGE) and sales growth (SG). Second, to analyze the relationship of financial performance with financial difficulties (FD) by including control variables, namely company size (SIZE) and company age (AGE).

Financial performance $_{i, t}=\beta_{0}+\beta_{1} I S D_{i t}+\beta_{2} I S T_{i t}+\beta_{3} S I Z E_{i t}+\beta_{4} A G E_{i t}+\beta_{5} S G_{i t}+e i$

Financial distress $_{i, t}=\beta_{0}+\beta_{1} I S D_{i t}+\beta_{2} I S T_{i t}+\beta_{3} R O A_{i t}+\beta_{4} T Q_{i t}+\beta_{5} S I Z E_{i t}+\beta_{5} A G E_{i t}+\beta_{6} S G_{i t}+e i$ 


\subsection{Research Results}

Table 1 presents descriptive statistics. Average financial difficulties is 1,478, which is above the standard deviation in the range of 0.07 and 2.63. The average financial performance (ROA) is 0.944 , which is above the standard deviation with a range of 0.03 and 9.28. The average insider ownership is 8,500. Insider ownership is between 1.01 and 45.12. Similarly, institutional ownership averaged at 46,079 above the standard deviation with a range between 6.39 and 80.68. The average company size is 16,880 with a range between 14,528 and 20,499. Furthermore, the average age of a company is 12.94 or 13 years with a range between 1 and 36 years after the IPO on the IDX.

Table 1 Research Variables

\begin{tabular}{lcccc}
\hline Variable & Mean & Std. Dev. & Minimum & Maximum \\
\hline FD & 1.478 & 0.572 & 0.07 & 2.63 \\
ROA & 0.944 & 0.058 & 0.03 & 9.28 \\
ISD & 8.500 & 6.877 & 1.01 & 45.12 \\
IST & 46.079 & 22.372 & 6.39 & 80.68 \\
SIZE & 16.880 & 1.527 & 14.528 & 20.499 \\
AGE & 12.944 & 8.978 & 1 & 36 \\
\hline
\end{tabular}

Note:

FD is significant continuous decline in profits; ROA is the Net profit/total asset; ISD is shareholdings by corporate insiders; IST is shareholdings by institutional investors with board representation; SIZE is the natural logarithm of book value of total assets; AGE is the number of years between incorporation and the calendar year end of each firm.

Table 2 presents the coefficient of correlations for pairs of variables. Correlation coefficient is a measure of the degree of linear relationship between two or more variables. There is negative correlation between ROA and FD ( $p$ $<0.05)$. ISD is negatively correlated with FD $(\mathrm{p}<0.05)$. IST was negatively correlated with FD $(\mathrm{p}<0.05)$. SIZE was positively correlated with FD $(\mathrm{p}<0.05)$ and AGE was negatively correlated with FD $(p<0.05)$. Then, a positive correlation exists between ISD and ROA $(\mathrm{p}<0.01)$. There is positive correlation between IST and ROA $(\mathrm{p}<0.01)$. ISD and ROA were positively correlated ( $\mathrm{p}$ $<0.01)$. The correlation between SIZE and ROA is positive $(p<0.01)$ and there is a positive correlation between AGE and ROA ( $p<0.01)$. 
La Ode Sumail / Governance and Financial Difficulties of Conventional Banks

Table 2 Correlation Matrix of Research Variables

\begin{tabular}{lcccc}
\hline Variable & Mean & Std. Dev. & Minimum & Maximum \\
\hline FD & 1.478 & 0.572 & 0.07 & 2.63 \\
ROA & 0.944 & 0.058 & 0.03 & 9.28 \\
ISD & 8.500 & 6.877 & 1.01 & 45.12 \\
IST & 46.079 & 22.372 & 6.39 & 80.68 \\
SIZE & 16.880 & 1.527 & 14.528 & 20.499 \\
AGE & 12.944 & 8.978 & 1 & 36 \\
\hline
\end{tabular}

Note: Correlations are significant at: ${ }^{* * 0.05}$ (two tailed) and $* * 0.01$ levels

To get an explanation between governance, financial performance, and financial difficulties, this study applies a regression analysis. After testing the Lagrange Multiplier (LM), the coefficient and probability values obtained for each model are $65.55(\mathrm{p}=0.0000)$ and $48.78(\mathrm{p}=0.0044)$, respectively. To confirm, this research uses the Fixed Effects model approach (see Table 3). The advantage of the model is reflected by the Adjusted R-squared, which is 47.37 percent and 48.99 percent, respectively. That is, the model can be stated as proper in explaining the relationships between variables.

Table 3 Estimation of Governance, Financial Performance, and Financial Difficulties

\begin{tabular}{lcc}
\hline \multicolumn{1}{c}{ Variabel } & $\begin{array}{c}\text { Model 1 } \\
\text { ROA }\end{array}$ & $\begin{array}{c}\text { Model 2 } \\
\text { NPL }\end{array}$ \\
\hline ROA & - & $-0.2765(2.83)^{* * *}$ \\
ISD & $0.4608(-7.32)^{* * * * *}$ & $-0.1393(2.72)^{* * *}$ \\
IST & $0.0883(5.06)^{* * * *}$ & $-0.0264(2.38)^{* * *}$ \\
SIZE & $0.2466(3.95)^{* * * *}$ & $-0.0706(2.12)^{* * *}$ \\
AGE & $0.0631(-3.48)^{* * * *}$ & $-0.0336(1.99)^{* * *}$ \\
Adjusted R-squared & 0.4737 & 0.4899 \\
F-ratio & 23.21 & 32.06 \\
Fixed effects & 65.55 & 48.78 \\
Number & 108 & 108 \\
Constant & 0.5404 & 0.1094 \\
& & \\
\hline
\end{tabular}

Note: "Statistical significance at the $5 \%$ level; "***statistical significance at the $1 \%$ level. 


\subsection{Discussion}

The estimation results of model 1 show that the relationship between insider ownership (ISD) and financial performance (ROA) is positive and significant. That is, the more insider ownership, the stronger the insider's drive to prioritize the interests of the owner, such as by making attractive investments to increase company profitability and reduce agency problems reduced (McConnell, Servaes, \& Lins, 2008). Table 1 shows that the minimum insider ownership is at 1 percent. This shows that the more insider ownership, the higher the financial performance. In this regard, Cheung \& Wei (2006) and Gugler, Mueller, \& Yurtoglu (2008) stated that insider ownership has a strong and significant effect on financial performance. As a result, agency problems can be reduced. An optimistic tone conveyed by Moon, Rao, \& Bathala (1994) was that one of the mechanisms for reducing agency costs is through increasing insider ownership.

The Jensen \& Meckling (1976) model defined agency costs as the sum of the costs incurred by the owner to supervise managers or insiders. It is almost impossible for companies to have zero agency cost in order to guarantee that managers will make optimal decisions from the view of shareholders because of the large differences in interests between them. Therefore, the presence of insider's share ownership can be used to reduce agency costs that have the potential to arise, because it is expected that by having company shares, the manager will immediately benefit from any decisions he makes. This process is called the bonding mechanism, which is a process to equalize the interests of management through a binding program of management in the company's capital.

There is also ownership at the 45 percent level. This can be interpreted that in certain conditions, the increase in insider ownership will actually reduce ROA. This is because people no longer find investing attractive anymore. As a result, profitability declined and agency problems began to emerge (Cheung \& Wei, 2006; Gugler et al., 2008). Long before, Bhabra, (2007) had a special view that when insider ownership is as much as 14 percent, it had a strong influence on the value of the company and if the insider ownership is above 40 percent, then it would be inversely proportional to the value of the company. Therefore, 
it can be stated that the relationship of insider ownership with ROA tends to be in the shape of an inverted U (Chen, Hou, \& Lee, 2012).

A positive and significant relationship was found between institutional ownership and ROA. The involvement of institutional investors is higher in the use of asset resources, so that the company's stock returns are good (Belghitar, Clark, \& Kassimatis, 2011). Much earlier, as Abdelsalam et al., (2008), Bhattacharya \& Graham (2009), and Elyasiani \& Jia (2010) reported, the greater the institutional ownership, the stronger the supervision and thus, financial performance was getting better in conventional private banks. This means that the involvement of institutional investors in monitoring and controlling activities reduces agency conflicts and improves company performance. In fact, institutional investors tend to be more careful about the company's stock return performance (Belghitar, Clark, \& Kassimatis, 2011).

Gumanti (2017: 267) stated that one of the patterns of agency conflict comes from the actors who do not have perfect information on every action carried out by other actors. Institutional investors have perfect information advantages when compared to other investors (Arjoon et al., 2016), so that agency conflicts can be avoided. Barinov (2017) held that institutional investors have perfect information so that they are able to hedge against the risk of aggregate volatility. However, Shin \& Tsung (2009) found a different view, one which stated that institutional investors had a significant negative correlation with company performance. This is suspected to be caused by the quality of information held by institution investors which tends to be low. As a result, company performance is low and agency conflicts tend to occur.

Large-scale companies will get good financial performance (ROA) because banks have sufficient assets to finance attractive investments so that ROA increases. Likewise, companies that are old or established tend to have good ROA. This is because the older the age or the more established the bank, the healthier the bank's cash flow so the potential for getting asset returns is quite high.

Empirical findings in Model 2 is the relationship between financial performance (ROA) and financial difficulties (FD) are negative and significant. Because ROA is getting higher, the potential for financial difficulties is lower. High ROA is indicated by strong governance so that the potential for financial 
difficulties is low. Shahwan (2015) stated that poor quality corporate governance practices will have an impact on low financial performance and higher potential to experience financial difficulties. At banks, financial difficulties are reflected by high Non Performance Loans (NPLs), so that liquidity is disrupted and some periods of profit tend to decline. High NPLs are suspected to be caused by poor governance (Abid, Ouertani, \& Zouari-Ghorbel, 2014), resulting in slower cash flow due to disrupted or low liquidity and a significant decline in earnings for two years or more. As it turns out, private conventional banks on the IDX have low NPL levels, therefore indicating that the bank cash flow is healthy. The implication is that bank liquidity is maintained and profits have increased significantly so that it can be stated that the bank will avoid financial difficulties.

The reality of conventional private banks on the IDX is different from the empirical evidence reported by Mselmi, Lahiani, \& Hamza (2017), stating that low profitability implies low financial performance and results in financial difficulties. This is caused by weak corporate governance. Lee \& Yeh (2004) stated that weak corporate governance is caused by several types of ownership structures and board composition which tend to result in the takeover of minority interests, which in turn reduces the value of the company and potentially causing financial difficulties.

Long before, Simpson \& Gleason (1999) stated that the likelihood of financial difficulties would be lower when there is only one CEO and one board of directors. In addition, the role of institutional ownership is to control financial performance and overcome financial difficulties. Empirical evidence, such as by Li, Wang, \& Deng (2008) and Manzaneque, Priego, \& Merino (2016) reported that institutional ownership negatively influences financial difficulties.

\section{CONCLUSION}

This study investigates the relationship of insider ownership with inverted or non-linear U-shaped performance and investigates the relationship of institutional ownership with performance and to empirically prove it. Therefore, this study uses a sample of research that is a private conventional bank on the Indonesia Stock Exchange as many as 27 samples within the period of 20152018 with 109 observations made. 
By increasing the ownership of insiders, their actions prioritize the interests of owners such as making attractive investments so as to increase bank profitability and reduce agency problems. However, at some point the increase in insider ownership actually reduces profitability so that it can be stated that the relationship of insider ownership with ROA tends to be shaped as an inverted U.

There is a significant positive relationship between institutional ownership and ROA. The greater the involvement of institutional investors in supervising assets causes good financial performance. High ROA is indicated by strong governance so that the potential for financial difficulties is low. Conversely, poor quality corporate governance practices will have an impact on low financial performance, and potentially causing financial difficulties. Financial difficulties are identified by NPL, liquidity, and profit decline. It turns out, if NPL is low, then bank cash flow is healthy, bank liquidity is maintained, and profits have increased significantly so it can be stated that banks will avoid financial difficulties. The measurement of bank governance only relies on insider ownership and institutional ownership, so this research believes financial difficulties are still reduced.

Future studies can cover more time periods using panel data analysis to consider short-term and long-term effects. Then, further studies can also consider more variables, both from the characteristics of the board and ownership structure such as government ownership and foreign ownership, because variations in ownership will complement bank governance information.

Large-scale banks and old or established banks are more likely to have high ROA. Because the larger the assets, the healthier the cash flow of the bank, thus the potential for getting asset returns is quite high and financial difficulties are low or avoidable. The theoretical implications is that in order to avoid financial difficulties, governance must be strong, especially in large scale and mature-aged bank assets. Then, the practical implications are that NPLs must be low so that bank cash flow is healthy and the bank will avoid financial difficulties. 


\section{REFERENCES}

Abdelsalam, O., El-Masry, A., \& Elsegini, S. 2008. Board Composition, Ownership Structure and Dividend Policies in an Emerging Market: Further Evidence from CASE 50. Managerial Finance, 34(12), 953-964.

Abid, L., Ouertani, M.N., \& Zouari-Ghorbel, S. 2014. Macroeconomic and Bank-Specific Determinants of Household's Non-performing Loans in Tunisia: A Dynamic Panel Data. Procedia Economics and Finance, 13(December 2014), 58-68.

Ahmad, A.C. \& Jusoh, M.A. 2014. Institutional Ownership and Market-based Performance Indicators: Utilizing Generalized Least Square Estimation Technique. Procedia - Social and Behavioral Sciences, 164(August), 477485 .

Al-najjar, B. 2010. Corporate Governance and Institutional Ownership: Evidence from Jordan. Corporate Governance, 10 (2), 176-190.

Al-tamimi, H.A.H. 2012. The Effects of Corporate Governance on Performance and Financial Distress the Experience of UAE National Banks. Journal of Financial Regulation and Compliance, 20(2), 169-181.

Anderson, C.W., \& Campbell, T.L. 2004. Corporate Governance of Japanese Banks. Journal of Corporate Finance, 10, 327-354.

Arjoon, V., Bougheas, S., \& Milner, C. 2016. Lead-lag Relationships in an Embryonic Stock Market: Exploring the Role of Institutional Ownership and Liquidity. Research in International Business and Finance, 38, 262276.

Barinov, A. 2017. Institutional Ownership and Aggregate Volatility Risk. Journal of Empirical Finance, 40(November 2016), 20-38.

Belghitar, Y., Clark, E., \& Kassimatis, K. 2011. The Prudential Effect of Strategic Institutional Ownership on Stock Performance. International Review of Financial Analysis, 20(4), 191-199.

Bhabra, G.S. 2007. Insider Ownership and Firm Value in New Zealand. Journal of Multinational Financial Management, 17(2), 142-154.

Bhagat, S. \& Bolton, B. 2008. Corporate Governance and Firm Performance. Journal of Corporate Finance, 14, 257-273. 
Bhattacharya, P.S. \& Graham, M.A. 2009. On Institutional Ownership and Firm Performance: A Disaggregated View. Journal of Multinational Financial Management, 19(5), 370-394.

Chen, M.H., Hou, C.L., \& Lee, S. 2012. The Impact of Insider Managerial Ownership on Corporate Performance of Taiwanese Tourist Hotels. International Journal of Hospitality Management, 31(2), 338-349.

Cheung, W.K.A., \& Wei, K.C.J. 2006. Insider Ownership and Corporate Performance: Evidence from the Adjustment Cost Approach. Journal of Corporate Finance, 12(5), 906-925.

Cornett, M.M., Marcus, A.J., Saunders, A., \& Tehranian, H. 2007. The Impact of Institutional Ownership on Corporate Operating Performance. Journal of Banking and Finance, 31(6), 1771-1794.

Demiralp, I., D’Mello, R., Schlingemann, F.P., \& Subramaniam, V. 2011. Are There Monitoring Benefits to Institutional Ownership? Evidence from Seasoned Equity Offerings. Journal of Corporate Finance, 17(5), 13401359.

Elyasiani, E. \& Jia, J. 2010. Distribution of Institutional Ownership and Corporate Firm Performance. Journal of Banking and Finance, 34(3), 606620.

Gugler, K., Mueller, D.C., \& Yurtoglu, B.B. 2008. Insider Ownership, Ownership Concentration and Investment Performance: An International Comparison. Journal of Corporate Finance, 14(5), 688-705.

Iqbal, M. \& Santhakumar, S. 2018. Information Asymmetry and Insider Trade Profitability in India. Journal of Indian Business Research, 10(1), 53-69.

Jensen, M.C. \& Meckling, W.H. 1976. Theory of the Firm: Managerial Behavior, Agency Costs, and Ownership Structure. Journal of Financial Economics, 3(4), 305-360.

Klapper, L.F. \& Love, I. 2004. Corporate Governance, Investor Protection, and Performance in Emerging Markets. Journal of Corporate Finance, 10, 703728.

Lee, T.S. \& Yeh, Y.H. 2004. Corporate Governance and Financial Distress: Evidence from Taiwan. Corporate Governance: An International Review, $12(3), 378-388$. 
Li, H.X., Wang, Z.J., \& Deng, X.L. 2008. Ownership, Independent Directors, Agency Costs and Financial Distress: Evidence from Chinese Listed Companies. Corporate Governance, 8(5), 622-636.

Manzaneque, M., Priego, A.M., \& Merino, E. 2016. Efecto del Gobierno Corporativo en la Probabilidad de Fracaso Empresarial: Evidencia Española. Revista de Contabilidad, 19(1), 111-121.

Martynova, M. \& Renneboog, L. 2008. Spillover of Corporate Governance Standards in Cross-Border Mergers and Acquisitions. Journal of Corporate Finance, 14, 200-223.

McConnell, J.J., Servaes, H., \& Lins, K.V. 2008. Changes in Insider Ownership and Changes in the Market Value of the Firm. Journal of Corporate Finance, 14(2), 92-106.

Moon, P., Rao, R.P., \& Bathala, T. 1994. Policy, Ownership, Managerial Impact of Institutional Holdings: A Perspective. Financial Management, 23(3), 3850 .

Mselmi, N., Lahiani, A., \& Hamza, T. 2017. Financial Distress Prediction: The Case of French Small and Medium-Sized Firms. International Review of Financial Analysis, 50(1), 67-80.

Oba, B., Ozsoy, Z., \& Atakan, S. 2010. Power in the Boardroom/ : A Study on Turkish Family-Owned and Listed Companies, 10(5), 603-616. 